\title{
Kas ir mācīšanās iedziḷinoties jeb kādā procesā mācīšanās rezultāts var būt kompetence
}

Dace Namsone, Zane Oliṇa

\section{Mācīšanās iedziḷinoties pazīmes}

Kompetenču attīstī̌sana tieši saistīta ar mācīšanos iedziḷinoties jeb mācību pieeju, ko dažādi autori angḷu valodā dēvē arī par deep learning (dziḷmācīšanās) jeb visible learning (ieraugāma, uzskatāma, redzama mācǐšanās) (Fullan, \& Langworthy, 2014; Hattie, 2012; u. c.) un ir šādas mācību pieejas rezultāts. Hjūleta Fonds (The Hewlett Foundation) definē mācīšanos iedziļinoties kā "visaptverošu/jumta jēdzienu, kas ietver tās prasmes un zināšanas, kurām būtu jāpiemīt skolēniem veiksmīgu darba gaitu uzsākšanai un pilsoniskās dzīves veidošanai 21. gadsimtā"1.

ASV Zinātṇu akadēmijas Nacionālās pētniecības padomes ziņojumā (National Research Council ${ }^{2}$ ), kurā izvērtēti prominentākie 21. gadsimta prasmju modelii, īpaši izcelta nepieciešamība mācību procesā panākt, ka skolēni mācās iedziḷinoties (deeper learning). Mācīšanās iedziļinoties, kā atzīmē ziņojuma autori, ir process, kura laikā skolēni attīsta spēju vispārināt jeb pārnest jaunās zināšanas un prasmes uz jaunām, nezināmām situācijām. Ir lielāka iespējamība, ka notiks

1 Hewlett Packard. (April 2013). Deeper Learning Competencies. Pieejams: http://www.hewlett. org/uploads/documents/Deeper_Learning_Defined_April_2013.pdf (aplūkots 22.10.2017.).

2 National Research Council. (2012). Education for Life and Work: Developing Transferable Knowledge and Skills in the $21^{\text {st }}$ Century. Committee on Defining Deeper Learning and $21^{\text {st }}$ Century Skills, J. W. Pellegrino, \& M. L. Hilton, Editors. Board on Testing and Assessment and Board on Science Education, Division of Behavioral and Social Sciences and Education. Washington, DC: The National Academies Press. 
pārnese, ja skolēniem ir izpratne par vispārējiem principiem un pieejām problēmu risināšanā, ja skolēniem ir gan faktolog̣iskas un kontekstuālas zināšanas attiecīgajā jomā, gan atbilstoši problēmu risināšanas paṇēmieni (strategy $\left.y^{3}\right)$, ja skolēni spēj atpazīt kā, kad un kāpēc izmantot faktologiskās (deklaratīvās), kontekstuālās un procedurālās zināšanas un prasmes.

Ziṇojuma autoru ieskatā, tāds arī ir 21. gadsimta caurviju jeb transversālo prasmju (transversal skills) integrācijas mērḳis - sekmēt mācǐšanās iedzilinoties procesus, tādējādi palīdzot skolēniem labāk un pamatīgāk apgūt mācību saturu. Ziņojuma autori norāda, ka šis pieejas izmantošana varētu samazināt mācību sasniegumu nevienlīdzību skolēnu vidū. Tādējādi lielāks skaits jauniešu būtu sagatavots sekmīgai dzīvei sabiedrībā un profesionālai darbībai.

Mācǐšanās iedziḷinoties ir process, kura laikā skolēni attīsta, nostiprina un izmanto augsta līmeņa domāšanas prasmes - analizē, sintezē, izvērtē, risina problēmas, lieto metakognitīvos paṇēmienus, lai konstruētu ilgtermiṇa izpratni. Mācīšanās iedziḷinoties ietver jaunu ideju vērtējošu analīzi, sasaistot tās ar jau esošajām, un šādas mācišanās pieejas mērḳis ir prast risināt problēmas jaunās, nezināmās situācijās (tostarp, reālās dzīves situācijās) un kontekstā jeb spēja pārnest. Šādas mācišanās pieejas priekšplānā izvirzās procesi, ar kuru palīdzību mēs iegūstam zināšanas (kā mēs zinām?), ne tikai uzkrātu noteiktu satura apjomu (ko mēs zinām?). Mācību stundas līmenī tas vispirms nozīmē mērķu izvirzīšanu, atgriezeniskās saites saņemšanu skolēniem, skolēnu pieredzes aktualizēšanu, apzinātu kognitīvo un metakognitīvo paņēmienu darbināšanu domas (jēgas) konstruēšanai dažādā kontekstā un situācijās, kā arī skolēnu sadarbību.

Mācišanās iedziḷinoties pamatmērḳis ir tiekties uz to, lai skolēns iegūtu padziḷinātu un konceptuālu izpratni par kompleksām/sarežğìtām tēmām. Šādu izpratni nav iespējams iegūt, ja skolēns apgūst tikai deklaratīvas zināšanas (faktus), kas ir tikai viena no kompleksa snieguma nepieciešamajām sastāvdal̦ām (Greene, \& Azavedo, 2009). Šai pieejai raksturīga skolēna aktīva intelektuāla iesaiste savas izpratnes veidošanā. Skolēns, iepazīstoties ar jauno informāciju, idejām, tās izvērtē un sasaista ar jau iepriekš iepazītiem jēdzieniem un principiem. Skolēnam rodas izpratne un stabilas zināšanas par jaunajiem jēdzieniem ilgterminnā, kas palīdz tos lietot un risināt problēmas jaunā un nepazīstamā kontekstā. Šādā mācību procesā notiek zināšanu integrācija, sintēze un refleksija (Vos, Meijden, \& Denessen, 2011).

Izmantojot šādu mācību pieeju, process vistiešākajā mērā ietekmē sasniedzamo rezultātu jeb faktiski ir ekvivalents rezultātam. Nevar teorētiski mācīt vērtības, ar tām ir jādzīvo. Nevar teorētiski mācīt par neatlaidību, šĩ

3 Tekstā anĝ̣u valodas termins strategy lietots kā paṇēmiens, lai gan profesionālajā ikdienā ieviešas termins "stratēgijas". 
spēja ir jāattīsta ikdienā, saskaroties ar uzdevumiem un situācijām, kur tā nepieciešama. Nevar teorētiski mācīties par iecietību, tā ir jāpraktizē attiecībās ar skolasbiedriem. Ticỉba intelekta mainīgajai dabai nevar rasties, ja skolēniem nav skaidri kritēriji, pēc kuriem viṇu darbu vērtēs, un izpratnes par to, ar kādām darbībām viṇi var savu sniegumu uzlabot. Jābūt arī reālai iespējai uzlabot savu darbu. Ideju par to, ka 21. gadsimta prasmju apguvei mācīšanās jeb darǐšana nav atraujama no sasniedzamā rezultāta, uzsver arī Maikls Fulans savā esejā "Izglìīiba ar plusa zīmi” (Fullan, \& Scott, 2014). Viņš aicina nostiprināt vēl nebijušu ideju izglìtībā, ka izglìtota persona ir darītājs - darošs domātājs jeb domājošs darītājs, kurš mācās, lai darìtu, un dara, lai mācītos.

Šādas pieejas mācībām īstenošanai ir vairāki iemesli - gan jau pirmajā nodaḷā pieminētās objektīvās izmaiņas sabiedrības attīstībā, kad līdzšinējās prasmes vairs nav pietiekamas un skolas beidzējiem jārēḳinās ar to, ka mācības būs jāturpina mūža garumā, gan arvien pieaugošais zinātnisku pētījumu apjoms par efektīvu mācǐšanās procesu un faktoriem, kas sekmē pārnesi jeb spēju lietot zināšanas kompleksās, nepazīstamās situācijās, pierādījumi, ka mācību pieeja, kurā skolotāja pamatdarbība vērsta uz gatavu zināšanu nodošanu skolēniem, ved pie trauslām, fragmentārām un pasīvām zināšanām, ierobežojot skolēna spēju tās sekmīgi izmantot dzīvē. Šādas zināšanas tiek dēvētas par fragmentārām, inertām, kūtrām, naivām, rituālām pretēji nepieciešamībai gūt dziḷu izpratni, skaidrojot, salīdzinot, sniedzot piemērus, pretstatot un vispārinot (Gardner, \& Perkins, 1988). Mācī̌anās iedzị̣inoties pieeja mācībām nozīmē gan paradigmatiski jaunu izpratni par to, kas ir nozīmīgs sasniedzamais rezultāts mācību procesā - spēja saskatīt problēmu, izvēelēties, izstrādāt un ieviest piemērotu risinājumu, darot to atbildīgi, patstāvīgi, kvalitatīvi u. tml. -, un tāpēc citādu skolotāja un skolēna lomu mācībās, gan noteiktu mācišanas un mācišanās paṇēmienu izmantošanu mācību procesā, piedāvājot iespējas vingrināties šāda integrēta snieguma demonstrēšanai.

ASV Zinātṇu akadēmijas Nacionālās pētniecības padomes ziṇojumāa ${ }^{4}$ uzskaitìtas skolotāja darbības, kas sekmē mācǐšanos iedzililinoties un tādējādi kompetences attīstību: sākt ar skaidri definētu sasniedzamo rezultātu un modeli jeb izpratni par to, kā noritēs mācǐšanās, lai to sasniegtu; izmantot vērtēšanu, lai novērtētu un atbalstītu skolēnu progresu ceḷā uz mērḳi; piedāvāt vairākus, daudzveidīgus piemērus un demonstrācijas apgūstamajiem jēdzieniem un uzdevumiem; rosināt

${ }^{4}$ National Research Council. (2012). Education for Life and Work: Developing Transferable Knowledge and Skills in the $21^{\text {st }}$ Century. Committee on Defining Deeper Learning and $21^{\text {st }}$ Century Skills, J. W. Pellegrino, \& M. L. Hilton, Editors. Board on Testing and Assessment and Board on Science Education, Division of Behavioral and Social Sciences and Education. Washington, DC: The National Academies Press. 
jautājumu uzdošanu un diskusijas; piedāvāt skolēniem izaicinošus, intelektuāli sarežḡitus uzdevumus, nodrošinot atbilstošu atbalstu un pārraudzību; mācīt, izmantojot rūpīgi izvēlētus piemērus un gadījumus; apzināti strādāt pie skolēnu motivācijas palielināšanas; izmantot formatīvo vērtēšanu, lai sniegtu atgriezenisko saiti.

Mācǐšanās iedziḷinoties ir pieeja palīdzēt skolēniem mācīties risināt uzdevumus līdzīgi tam, kā tas notiktu viṇu turpmākajā profesionālajā darbībā (Fullan, \& Langworthy, 2013).

Skolēna mācīšanās dziḷumu lielā mērā nosaka mācīšanas paṇēmieni, kurus izmanto skolotājs. Skolēnu mācǐšanās dziḷums atkarīgs no mācību uzdevumu kompleksuma, kas prasa atbilstošu skolēna sniegumu. Šajā procesā notiek mācību satura un zināšanu integrācija, sintēze un refleksija (Vos, Meijden, \& Denessen, 2011).

Apkopojot varam konstatēt, ka mācīšanās iedziḷinoties (deep, deeper learning) nozìmē:

- padzilịnātu skolēna motivāciju un interesi par mācību uzdevuma saturu;

- fokusēti saprast mācību satura būtību;

- saistīt mācību satura elementus savā starpā;

- sasaistìt jaunas idejas ar iepriekš apgūtajām zināšanām;

- sasaistìt jēdzienu ar ikdienas pieredzi (Chin, \& Brown, 2000; Fullan, \& Scott, 2014; Hattie, 2012).

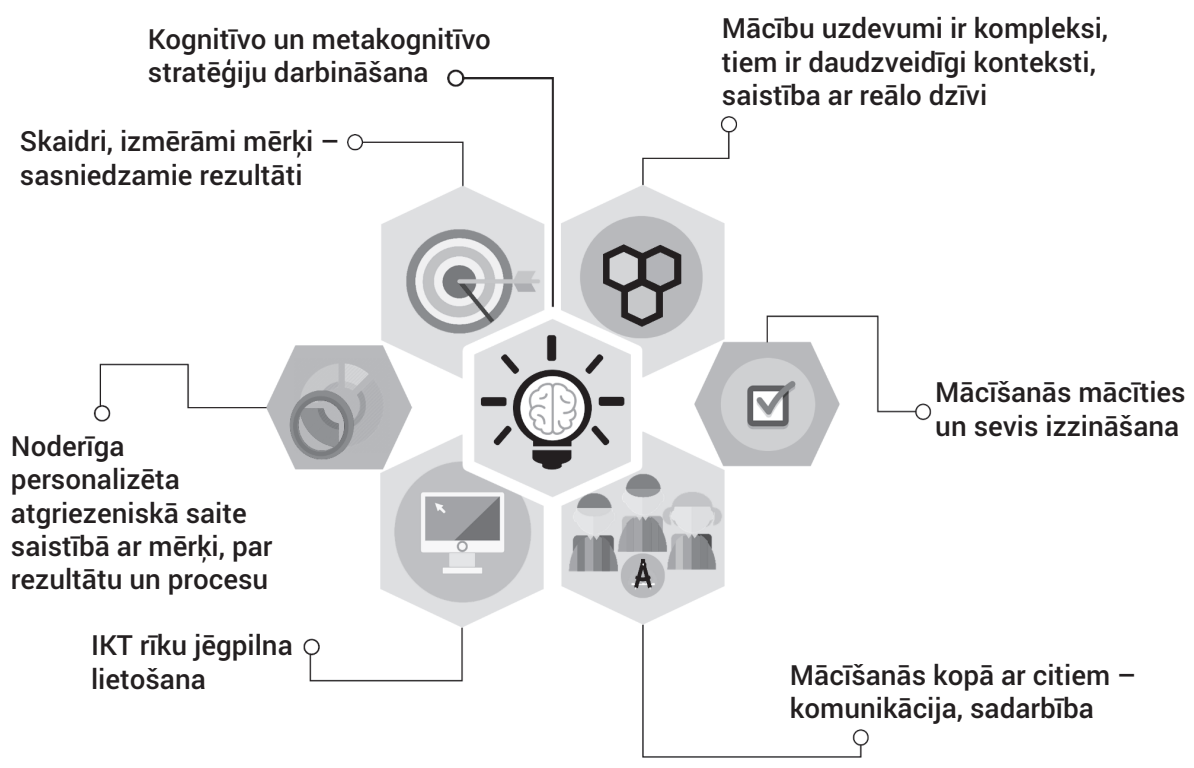

1. attēls. Pazīmes, kas raksturo mācīšanos iedziḷinoties (LU SIIC arhīvs) 
1. attēlā apkopotas svarīgākās pazīmes, kas raksturo mācīšanos iedziḷinoties - skaidrs, izmērāms, skolēnam saprotams mērḳis jeb sasniedzamais rezultāts; noderīga, personalizēta, attīstoša atgriezeniskā saite; kognitīvu un metakognitīvu mācīšanās pañēmienu darbināšana kompleksu mācỉbu uzdevumu risināšanā, kas doti daudzveidīgos kontekstos; mācišanās norisinās kopā ar citiem, jēgpilni lietojot informācijas un komunikācijas tehnologijas.

İstenojot šādu pieeju mācībām, jāmainās gan uzskatiem par skolotāja lomu mācību procesā, gan veidam, kā skolas līmenī tiek plānots un organizēts mācību darbs un vērtēšana, gan katra skolotāja darbam klasē.

Tālāk piedāvāsim teorētisko pamatojumu mācišanās iedziḷinoties pieejas iedzīvināšanai no skolēna mācišanās viedokḷa un detalizētāk ar piemēriem raksturosim mācišanas paṇēmienus efektīiākas mācīšanās sekmēšanai.

\section{Mācīšanās iedziḷinoties pieejas teorētiskie aspekti no skolēna mācīšanās viedokla}

Kopš 20. gadsimta 70. gadiem dažādās mācǐšanās teorijās aprakstot mācīšanās procesu no skolēna viedokḷla, izmantoti jēdzieni "virspusēja mācišanās" un "māciššnās iedziḷinoties" (surface learning vs deep learning). Virspusēja mācīšanās saistās ar zema līmeṇa mācǐšanās rezultātu (learning outcomes) jeb trauslām, fragmentētām zināšanām, bet mācīšanās iedziḷinoties - ar augsta līmeņa rezultātu (Marton, \& Säljö, 1984; Biggs, 1987; Entwistle, 2001) jeb patiesu izpratni, spēju vispārināt un pārnest iegūtās zināšanas un prasmes uz jaunām, nepazistamām situācijām.

Virspusēja mācīšanās raksturīga tiem brīžiem mācišsanās procesā, kad skolēns cenšas jaunu informāciju iegaumēt no galvas (Biggs, Kember, \& Leung, 2001). Atsevišķi fakti tiek iegaumēti, norādes un procedūru gaita tiek reproducētas, tās atkārtojot un iegaumējot (rote learning). Skolēni neredz uzdevuma sasaisti ar citiem uzdevumiem, situācijām no reālās dzīves, viṇi to uztver kā pienākumu, kas jāizpilda (Chin, \& Brown, 2000, p. 110). Ja skolēns mācību stundā izmanto virspusējas mācišanās pieeju, skolēns reproducē vai kategorizē informāciju, atdarina vienkāršotas darbības (procedūras) (Smith, \& Colby, 2007, pp. 205-206). Šìs pieejas ietvars nosaka to, ka mācīšanās procesā skolēna iesaistišanās līmenis ir zems, fokuss ir uz iegaumēšanu vai darbïbu veikšanu bez reflektēšanas un mācǐšanās nodoms ir saņemt nepieciešamo sekmīgo atzīmi (Marton, \& Säljö, 1984).

Jebkurai mācišanās pieejai raksturīgi divi elementi: 1) stratēgija - skolēnu darbības; 2) nodoms - kāpēc skolēni veic šis darbības (Marton, \& Säljö, 1984). Tāpēc mācǐšanās iedziḷinoties pieejā svarīgi ir definēt sasniedzamo rezultātu un par to kopīgi diskutēt. Šīs mācīšanās pieeja ietver nodomu izprast un piešḳirt 
nozīmes. Skolēns piešķir uzmanību attiecībām, kas pastāv starp mācību satura elementiem un aspektiem, izvirza hipotēzes vai pieņēmumus par problēmu vai jēdzienu struktūrām. Pieeja arī saistās ar to, ka tiek iegūta patiesa interese par mācǐšanos un izpratni (Marton, \& Säljö, 1984).

No abu pieeju īsās analīzes ir novērojams, ka šīs tiešām ir pieejas, kas ietekmē to, kas mācišanās procesā notiek ar skolēnu. Skolotājs ar izvēlēto mācīšanas metodi var sekmēt vienu vai otru pieeju mācībām no skolēna viedokḷa. Skolotājs fokusējas uz mācǐšanu kā skolēna personīgās izpratnes radīšanu (Entwistle, $2000^{5}$ ). Jebkuru mācīšanās pieeju nevajadzētu uzlūkot kā skolēnam piemītošu nemainīgu, tikai viņam raksturīgu , bet gan kā viņa atbildi un reakciju uz doto (mācǐšanās/mācǐšanas) situāciju (Marton, 1983; Ramsden, 1988). Citiem vārdiem, skolēns attiecīgi reagêe uz to, kā skolotājs organizē mācību darbu stundā. Pētijjumi ir pierādījuši, ka skolotāji savā mācību praksē adaptē vai nu dziļas, vai virspusējas mācīšanas pieeju (Boulton-Lewis, Smith, McCrindle, Burnett, \& Campbell, 2001; Smith, Gordon, Colby, \& Wang, 2005). Tas ir izplatīts novērojums arī augstākajā izglìīibā (Trigwell, Prosser, \& Waterhouse, 1999).

Skolēna mācišanās nereti izpaužas vairākās dimensijās. Atsevišķos kontekstos skolēni var atspoguḷot padzịlinātāku mācišanās pieeju. Skolotāja uzdevums ir ievērot to dimensiju, kurā notiek padziḷināta mācǐšanās pieeja, un izmantot to kā pirmo atskaites punktu, no kura vadīt skolēnu uz padziļinātākiem domāšanas lìmeņiem (Chin, \& Brown, 2000, p. 131). Mācīšanos iedzịlinoties var veicināt, mudinot skolēnus pašiem formulēt jautājumus, skaidrojumus, prognozes un eksperimentēšanu vai pat veidot minimālus teorētiskus skaidrojumus mācību stundās (Chin, \& Brown, 2000, p. 133).

Mācību stundas kontekstā nozīme ir arī tam, kura mācišanās pieeja tiek lietota izteiktāk. Ir vairāki pētỉjumi, kuros mācišanos iedziḷinoties pieeju apskata kontekstā ar informācijas tehnolog̣iju lietošanu. Mācīšanās ar šiem rīkiem var veicināt mācǐšanos iedziḷinoties (Vos, Meijden, \& Denessen, 2011).

Konstruktīvisma (teorija par to, kā prāts rada zināšanas) filozofijas un ar to saistìto mācišanas un mācišanās teoriju kopums visprecīzāk/vistuvāk raksturo un skaidro mācišanās iedziḷinoties pieejas nepieciešamību. Atbilstoši konstruktīisisma teorijai (Piažē, Vigockis, Novaks, Ozbels, Niazs u. c.) apjēgšana norisinās kā jaunu zināšanu, prasmju konstruēšana, nevis vienkārši atcerēšanās (Niaz, 2008). Tā ir iespējama, ja ir skaidrs, kas jāapgūst (sasniedzamais rezultāts jeb mācī̌sanās mērḳis), ja tiek aktualizēts iepriekš apgūtais, tiek veicināta skolēna motivācija; rezultāts ir tad, ja skolēns pašnovērtē apgūto pret plānoto mērḳi. Atbilstoši šai

5 Entwistle, N. (2000). Promoting deep learning through teaching and assessment: Conceptual frameworks and educational contexts. Paper presented at the Teaching and Learning Research Programme Conference, November, in Leicester. 
teorijai skolēnam apgūstamais mācību saturs (zināšanas, izpratne, prasmes u. c.) netiek uzskatīts par statisku, ko otram cilvēkam var nodot kā gatavu kopumu un otrs to atceras, bet gan veidojas individuāli atšksirīga jēga uz tās pieredzes bāzes, kas jau ir izveidojusies. Konstruktīvisma teorija aplūko mācǐšanos no aspekta, kā prāts rada zināšanas, izmantojot jēdzienus (concepts, preconcepts); tā aplūko arī maldīgo priekšstatu (missconceptions) veidošanās risku. Plānojot sasniedzamo rezultātu, vienlaikus ar mācību satura idejām tiek plānota skolēna kognitīva darbiba.

Vēl viena mācīšanās iedziḷinoties pieejai raksturīga pazīme ir uzsvars uz sistemātisku skolēna paša iesaisti savas mācišsanās darbības plānošanā un vadīšanā. Pašvadīta mācišanās (self-direct learning) ir process, kurā skolēns darbina un lieto domāšanas, emocionālo stāvokḷu un uzvedības regulēšanas rīkus, lai sistemātiski orientētu sevi uz personisko mācību mērḳu sasniegšanu (Schunk, \& Zimmerman, 2011, p. 1).

Nozīmīgs mācǐšanās aspekts ir tas, lai ne tikai skolotājam, bet arī skolēnam katrā stundā ir skaidrs mācīšanās mērḳis (sasniedzamais rezultāts) un ko skolēns spēs, stundai beidzoties. Skolēna mērḳis, ko izvirzām, ir daudzdimensionāls. Tam jāatbilst laba mērḳa izvēles kritērijiem - jābūt konkrētam un skaidri saprotamam, izmērāmam, izaicinošam, bet reāli konkrētajiem skolēniem sasniedzamam, tā îstenotājam nozīmīgam (relevant), saistītam ar kopējo saturu un skolas mērḳiem, īstenojamam atvēlētajā laikā. Mērḳu apzināta izvirziššna skolēnam plānojama, sākot no pirmajām skolas dienām.

Pašvadīta mācǐšanās ietver arī mācišanās pārnesuma pašapzināšanu (apzinātas līdzības meklēšanu) jeb metakognitīvu darbību, kas ir izšķiroša, lai skolēns apgūtu mācišanās rīkus apzināti. Atslēgas jautājumi, uz kuriem skolēnam jāatbild, ir:

- vai šeit kaut kas man atgādina kaut ko no iepriekš mācītā?

- kā šì problēma līdzinās tai, kuru risināju senāk (šajā vai citā priekšmetā, ikdienas situācijā, ...)?

Metakognitīvs process ir izglîtības process, kas ietver zināšanas par skolēna spējām (abilities), dotā uzdevuma prasībām un potenciāli efektīvākajiem mācīšanās paṇēmieniem. Tas iekḷauj pašvadību caur plānošanu, prognozēšanu, pārraudzī̌sanu, regulěšanu, vērtēšanu, pārskatǐšanu (O’Toole, 2005). Praktizējoties (vingrinoties) skolēnam tiek mācìts ar metakognitīvajiem rīkiem atpazìt: kur šo jau esmu redzèjis?; ar ko man tas saistās?; ar kädu paņēmienu šis tika risināts fizikā?; kā mēs meklējām teksta jēgu valodā? Vingrināšanās nozīmē aktualizēšanu ar jēgu, apgūto lietojot dažādā kontekstā, nevis "drillěšanu" (vienmuḷu atkārtošanu abstraktās situācijās).

Skaidrs un saprotams sasniedzamais rezultāts skolēnam, attīstoša atgriezeniskā saite, laiks domāt, sistemātiska, akumulēta (accumulated) un veiksmīga 
praktizēšanās, regulāri atkārtojot apgūto; savas izpratnes vai prasmju attīstības regulāra pārraudzība (monitoring) ir svarīgi nosacỉjumi, lai notiktu mācišanās (Hattie, \& Yates, 2013). Atgriezeniskās saites nozīmīgumu uzsver daudzi pētnieki. Džons Hatijs (John Hattie) ietekmes faktoru (effect size; kur vidējā ietekme 0,4) rāda, ka ietekmes faktors "atgriezeniskajai saitei” ir 0.72, "izaicinošu mērķu izvirzǐšanai” 0.56, "metakognitīvajām stratẹgijām" 0.67; "mācīšanās sadarbojoties" 0.59 (Hattie, 2009).

1. tabulā parādīta Latvijas Universitātes Starpnozaru Izglìtības inovāciju centrā (LU SIIC) izveidota darba lapa, kurā apkopotas svarīgākās pazīmes, kas raksturo skolēna mācišanos iedziļinoties. Darbības apkopotas, analizējot teorētisko literatūru un LU SIIC veiktu pētījumu (periodā 2011.-2017.) datus par skolotāju stundu vērojumiem. Tas tālāk pilnveidotas LU SIIC darbā, ìstenojot profesionālo pilnveidi dažādu mācību priekšmetu skolotājiem un skolu vadìtājiem.

Iepriekšêjā sadal̦ā detalizēti apskatijām teorētisko pamatojumu mācišanās iedziļinoties pieejai no skolēna viedokḷa, īpaši uzsverot konstruktīvisma filozofijai un ar to saistītām mācišanas un mācišanās teorijām raksturīgo uzsvaru uz skolēna aktīvo lomu un pašvadītas mācišanās nozīmi patiesas izpratnes, pamatīgu un ilgtermiņa zināšanu konstruēšanā. Uzsvērām, ka no skolēna mācišanās viedokḷa ir svarīgi, ka mācišanās procesā viṇam tiek dota iespēja un laiks pašam skolotāja sistemātiskā vadībā veidot savu izpratni par mācību saturu jeb konstruēt zināšanas. Lai tas notiktu efektīvi, nepieciešams panākt skolēna aktīvu, apzinātu un stratēgisisku iesaisti jeb mācišanos iedzị̣inoties. Tādēl mācišanās skolēnam jāpadara redzama/ieraugāma, t. i., ne tikai skolotājam, bet arī skolēnam jābūt skaidram mācišanās mērḳim un izpratnei par to, kādā ceḷā to ir iespējams sasniegt. Skolēnam nepieciešamas prasmes lietot efektīvus mācišanās paṇēmienus un vēlmi tos izmantot, lai paṇemtu pēc iespējas vairāk no katras mācišanās situācijas.

\section{Mācīšanas iedziḷinoties pazīmes mācību stundas līmenī}

Veidojot mācību stundu, skolotājam svarīgi ņemt vērā faktorus, kas sekmē efektīvu mācǐšanos, izvirzot skaidru sasniedzamo rezultātu, plānojot atgriezenisko saiti, paredzot laiku praktizēties u. c. Sākot mācīšanu, ir svarīgi izvirzìt sasniedzamo rezultātu (ko skolēns gūs mācoties) un saprast, kāpēc tas, ko mēs mācīsimies, skolēnam ir vajadzīgs, ne tikai domājot par mācību saturu, bet arī par veidu, kādā tiks organizēts mācīšanās process. Nozīmīgi skolotājam ir trīs jautājumi: kas ir tas, ko vēlamies sasniegt?; kā varu panākt, lai skolēni to iemācās?; kā zināšu, ka skolēni rezultātu sasnieguši? (Reece, \& Walker, 2007). 
1. tabula. Mācību stundu analīzes lapa "Es kā skolēns stundā mācos" (LU SIIC arhīvs)

Skolēna mācīšanās darbīibas

Ir/nav
Pierādījumi mācību stundā vērotajam

Zinu mērḳi, kas man jāsasniedz, kas jāiemācās

- tas ir par saturu, kas man jāapgūst

- es skaidri saprotu, ko no manis sagaida, kādi ir laba snieguma kritēriji

- tas būs interesanti

- tas man ir izaicinājums, bet es to varēšu

Mācos

Par katru mācību uzdevumu, ko saṇemu:

- skaidrs, kas jādara

- skaidrs, kā jādara

- skaidrs, kāpēc to daru, kā tas saistās kopā

Kā notiek mācīšanās:

- man ir iespēja, laiks domāt

- man ir iespēja praktizēties, vingrināties

- man ir iespēja iesaistīties, jautāt, piedāvāt, izteikties

Metakognitīvais lïmenis:

- man ir jādomā par to, kādā veidā es mācos, kā es domāju, atceros

Sadarbība:

- man ir iespēja darīt kopā ar klasesbiedriem

- skolotājs mani atbalsta

Dažādi mācību rīki, līdzekli:

- es izmantoju IT

- izmantoju piederumus, ierīces

- izmantoju dažādus informācijas avotus

Saprotu, ko iemācījos:

- man ir iespēja pārliecināties, kā man izdodas

- mācos/protu dot atgriezenisko saiti klasesbiedriem

- mācos/protu sañemt atgriezenisko saiti no skolotāja un klasesbiedriem

- par rezultātu (kas sanāca?)

- $\quad$ par veidu, kā mācījos (kā darīju?)

- saprotu, ko darīt turpmāk 
Efektīvām mācībām svarīga ir skolēnam skaidra stundas struktūra. Tieši stratēgiskā skaidrība (teachers clarity) (vai katram klasē sēdošajam ir skaidrs, kas šeit notiek?) ir viens no faktoriem ar augstu ietekmi uz rezultātu (effect size 0,75 salīdzinājumā ar 0,4 vidēji; Hattie, 2009). Efektīvas stundas struktūras izveides plānošana sākas ar atbildēm uz jautājumiem Ko gribu panākt? un Kā zināšu, ka rezultāts ir sasniegts? Pēc tam logiski jāstrukturē skolotāja un skolēnu darbību secība stundā, par atskaites punktu izvirzot plānoto skolēnam sasniedzamo rezultātu (Kà es to panākšu?).

Magdalēna Lamperta (Magdalene Lampert), salīdzinot divas matemātikas stundas, kurās abās ir iespējams apgūt vienu un to pašu matemātikas saturu ar dažādām pieejām - vienā tradicionālā veidā, otrā mācoties iedzilinoties -, raksta: "Balstoties uz maniem novērojumiem klasēs, es aprakstu, kā divi skolotāji savās mācību stundās mācỉja saturu un kādas darbības skolēni veica, lai to apgūtu. Vienā gadījumā fokuss tika likts uz mācīšanos iedziḷinoties, otrajā - ne. Pievēršot uzmanību detal̦ām, kḷūst skaidrs, ka mācīšana iedziḷinoties attiecas uz ko plašāku par šo konkrēto mācību stundu. Šì pieeja pieprasa, lai mēs balstìtu katru saskarsmes elementu starp skolēnu un skolotāju jaunā izpratnē par to, ko nozīmē mācìt un ko nozīmē mācìties" (Lampert, 2015, p. 9; skat. 2. tabulu).

Skolotājs staigā pa klasi un runā veidā, kas iesaista skolēnus nosacīti "publiskā” mācīšanās procesā, uzklausot viṇus un piedāvājot vinu domu gaitu pārējiem skolēniem apspriešanai. Skolotājs kopīgi ar skolēniem konstruē idejas, strādā sadarbojoties, lai radītu un veidotu kopīgu izpratni, piemēram, par matemātiskiem jēdzieniem vai prasmju apguvi latviešu valodā. 
2. tabula. Divu skolotāju redzējumu salīdzinājums (adaptēts pēc Lampert, 2015, p. 19)

\begin{tabular}{|c|c|c|}
\hline & $\begin{array}{l}\text { Skolotājs novēro skolēna } \\
\text { zināšanas netieši }\end{array}$ & $\begin{array}{c}\text { Skolotājs novēro skolēna } \\
\text { zināšanas tieši }\end{array}$ \\
\hline $\begin{array}{l}\text { Skolotājs uzlūko } \\
\text { zināšanas kā } \\
\text { nemainīgas/fiksētas } \\
\text { un meklē saskaṇu starp } \\
\text { skolēna zināšanām un } \\
\text { fiksētajām zināšanām. }\end{array}$ & $\begin{array}{l}\text { Skolotājs izmanto vairāku } \\
\text { atbilžu testus, mājasdarbus, } \\
\text { izdales materiālus u. c., lai } \\
\text { pārbaudītu skolēnu zināšanas. } \\
\text { Skolotājam minimāli } \\
\text { nepieciešamas saskarsmes } \\
\text { spējas un zināšanas, lai } \\
\text { lietotu izpētes paṇēmienus. }\end{array}$ & $\begin{array}{l}\text { Skolotājs izmanto vienkāršus } \\
\text { jautājumus, atbildes vai } \\
\text { formālu atkārtošanu, lai } \\
\text { pārbaudītu skolēnu zināšanas. } \\
\text { Skolotājiem nedaudz } \\
\text { nepieciešamas saskarsmes } \\
\text { spējas; zināšanas un } \\
\text { spēja formulēt atbilstošus } \\
\text { jautājumus un ātri izvērtēt } \\
\text { skolēnu atbildes. }\end{array}$ \\
\hline $\begin{array}{l}\text { Skolotājs uzlūko } \\
\text { zināšanas kā izziṇas } \\
\text { procesa iznākumu } \\
\text { un meklē norādes uz } \\
\text { domāšanu darbībā } \\
\text { (signs of minds at work). }\end{array}$ & $\begin{array}{l}\text { Skolotājs izmanto esejas, } \\
\text { pierakstu veikšanu un līdzīgus } \\
\text { pan̄ēmienus, lai pētītu, ko } \\
\text { skolēni zina un kā viṇi to } \\
\text { māk izklāstīt. Skolotājam } \\
\text { nepieciešamas saskarsmes } \\
\text { spējas un zināšanas, viṇam } \\
\text { nepieciešamas specializēta } \\
\text { satura zināšanas, lai } \\
\text { uzdotu labus jautājumus un } \\
\text { pārdomāti atbildētu uz skolēnu } \\
\text { jautājumiem. }\end{array}$ & $\begin{array}{l}\text { Skolotājs organizē sarunas, } \\
\text { diskusijas, debates, } \\
\text { pagarinātus kolokvijus } \\
\text { un līdzīgas tiešā diskursa } \\
\text { metodes, lai noskaidrotu, } \\
\text { ko skolēni zina. Skolotājam } \\
\text { nepieciešamas zināšanas par } \\
\text { saturu, prasmes sadarbībai ar } \\
\text { skolēniem un spēja savienot } \\
\text { šos elementus. }\end{array}$ \\
\hline
\end{tabular}

Šādas stundas būtiskas sastāvdaḷas ir apgūstamās satura jēgas noskaidrošana, ieraudziššna, kā to dara, paṇēmienu mācīšanās, kā darīt; domāt un sarunāties par to, kā personīgi es to daru. Tālāk dots konkrētas latviešu valodas stundas 4. klasē piemērs, kā skolotāja A. veido šādu stundu. 


\section{4. klase, latviešu valoda, skolotāja $A$.}

Skolotāja saka: "Lai saprastu, kas ir tēma, aicināšu paklausīties un vārdu spēlē atrast, ko šodien mācīsimies." Skolēni dažas sekundes klausās dziesmu "(..) jāj pa celu pasacina". Skolēni reaǵē, ka atpazīst. Skolotāja jautāa, kas ir autors, par ko ir dzejolis. Piebilst, ka šodien loti vēlētos, lai skolēni uzrakstītu pasaciṇu par tēmu, kurā viṇi atklātu fantāzijas lidojumu, un lai pasaka atškirtos no citiem prozas darbiem.

Skolotāja saka: "Lai saprastu, kā pasaka atškiras no citiem darbiem, jāapkopo savas zināšanas." Izdala lapas; uz lapas ir septini jautājumi; jāapvelk viena no trim iespējamām atbildēm. Kādā grupā viens iekrāso pareizo atbildi; citā grupā meitene uzṇemas lasīt visiem priekšā; ir atbilžu varianti; prasa, kuru apvilkt.

"Izlasīsim, kas mums no tā ir sanācis, kas ir pasaka?" Skolēni tiek saukti pa vienam un rosināti lasīt pa teikumam, kas ir pasaka. Skolotāja aicina pateikt vienu konkrētu atškirīibu. Klausās. Jautā, ko pārējie par šo saka. Kā varētu sākties pasaka? Reiz sensenos laikos; aiz kalniem un mežiem..., reiz dzīvoja..., kādu dienu. Pēc sākuma atpazīstam, kas ir pasaka. Vai pasaka ir gabaldarbs? Kas ir svarīgi, lai uzrakstītu pasaku? Kā sauc tās dalas? Kā sauc sākumu? levads? Kādas vēl dal as? Raksta uz tāfeles: ievads, galvenā dala, nobeigums. Uzsver, ka tas ir loti svarīgi. "Ko gribam nobeigumā redzēt?" Kā notikums beidzas. "Kā parasti beidzas?"

Uz tāfeles dažādi vārdi, kas iederas šajās dalāâs. Skolotāja jautā, kurā dalā iederas šie vārdi. Aicina katru grupu piespraust pie tāfeles vienu vārdu. Skolēni iet pa vienam no grupas un piesprauž. Grupas sarunājas par vārdiem. Vārdi: Kā tas sākās; Dzīves gudrība; Tēlu apraksts; Atrisinājums; Virsraksts; Notikumi; Pamācība; Vide; Sarežǵỉjumi un problēmas; Pozitīvs nobeigums.

Skolotāja aicina: "Pavērojam!" Jautā: "Vai ievadā runājam par...?" Apskata vārdus un veido sarunu par piemēriem ar šiem vārdiem. Apstājas pie virsraksta un jautā par virsrakstu. "Padomā, pirms dari; Mūžu dzīvo, mūžu mācies; Dari, ko darīdams, apdomā galu."

“Tu saproti, kas kurā dalā būtu jāraksta? Atveriet aploksnes, tajās ir vārdi, kas ir jāsavirknē ievada teikumā; bīdiet vārdus, līdz sanāk loǵisks teikums. Bīdiet, līdz izmantoti visi vārdi." Skolēni grupās liek teikumu. Skolotāja grupām dod konkrētus ieteikumus: "Jūs varētu likt strīpā, jo tad..." Aicina vienu grupu teikumu nolasīt visiem skali kopā. Vaicā, vai kādam ir citādāk, skolēni lasa.

Teikumi atškiras ar vienu vārdu. Katrs pats padomā, kāds varētu būt virsraksts. Ja ir ideja, pacel roku. Skolotāja uz tāfeles raksta virsrakstus, ko sauc skolēni. "Jautrā princese. Trīs kēniṇi. Atraktīvā princese. Skaistā princese. Dusmīgais karalis". Skolotāja pārjautā un komentē: "Kāpēc gan ne?!"

Skolotāja aicina uzrakstīt, kas pēc šāda ievada varētu notikt turpmāk. "Strādāsim tikai ar turpinājumu!" Skolotāja vēl pieliek klāt divus virsrakstus "Negaidītās pārmaiṇas. Pazaudētā prieka vācelīte";" Varbūt kādam noder." Skolēni individuāli raksta burtnīcās. "Es uzlikšu loti klusu mūziku, vai tas netraucēs?" 
“Uz katra stūra uzlikšu lapiṇu, kas tev var palīdzēt, ja neraisās domas." Uz lapiṇas kontrollapa ar jautājumiem: "Vai visi apkārtējie arī ir tik dzīvespriecīgi? Kas princesi satrauca vai apbēdināja? Ko darīja princese? Kas palīdzēja? Kā tas beidzās?" Skolotāja staigā pa klasi. Ir klusums, notiek darbs.

Rosina turpināt mājās.

Skolotāja jautā: "Kurš gribētu nolasīt?" Aicina klausīties ar domu, vai cilvēks, kurš to ir rakstījis, ir ievērojis šos noteikumus: vai ir notikumi, sarežǵĭjumi, problēmas? Klausies uzmanīgi, vai tev ir savs viedoklis? Elizabete lasa. Skolotāja jautā, vai ir notikums, sarežǵíjums Elizabetes problēmā? Lasa Anna. Skolotāja jautā: "Vai tu, Anna, n̦ēmi vērā, ka bija ievads? Es tev ieteiktu vēlreiz pārdomāt, kā skanēja teikums. Tagad tev ir drīzāk ir jauna, bet skaista pasaka." Annija runā no galvas. Skolotāja komentē: "Domas skrien pa priekšu ātrāk, nekā tu spēj uzrakstīt." (lepriekš aicināja lasìt uzrakstīto.)

Mājas uzdevums uz A4 lapas. "Mēs aiziesim pie 1. klases Labo darbu nedēlā un nolasīsim uzrakstīto viniem priekšā. Tu saṇemsi mazu lapiṇu, un iesāktajiem teikumiem būs jāuzraksta nobeigums; šo lapiṇu es gribēšu atpakal,." "Es šajā stundā sapratu...; Rakstīt pasaku ir svarīgi...; Es pats vēl neprotu..." "No tā atkarīgs, ko mēs darīsim nākamajā stundā." "Vai mēs varētu padalīties: "Es šajā stundā sapratu..."' Lìva: "Jādabū iztēle!" Jautā: "Vai tu dabūji to, kas tev palī́lzēja? Loti labi!" Cits skolēns: "Es šajā stundā sapratu, kā labāk rakstīt." Jautā: "Kas tev palīdzēja?" ledvesma. Aicina pacelt roku, kurš zina, ko rakstīt ievadā, saturā, nobeigumā.

Kā pieeju atškiriība izpaužas konkrētos mācību stundas elementos atkarībā no skolotāja izvēles?

Svarīgi ir nosacījumi mācǐšanās mērķu (skolēniem sasniedzamo rezultātu) izvirzišanai:

- mērḳi ir saskaṇā ar mācǐšanās būtîbas kopainu (piemēram, izglìtības standartu);

- mērḳi fokusējas uz mācišanos (mēs mācāmies, lai...);

- mērḳi ved uz māciššnos iedziḷinoties un transversālo prasmju un prakšu apgūšanu;

- mērķi ir reāli un sasniedzami dotajā laika ietvarā (mācību stundas laikā);

- mērksi ir skolēniem kopīgi un saprotami (formulēti vecumam atbilstošã valodā, izskaidroti, pārrunāti ar skolēniem tā uzstādīšanas sākumposmā - mācību stundas sākumā) (Andrade, \& Heritage, 2017, p. 43).

Pārliecināšanās par sasniegto rezultātu pret plānoto mācību stundā ar tai sekojošu attīstošu atgriezenisko saiti katram skolēnam ir neiztrūkstoša šādas stundas daḷa. Vairums formālo testu (summatīvo mērijumu) kā vērtēšanas pieejas mēra spēju atcerēties kaut ko (Bloom, 1956), kas ir virspusējas mācīšanās pieejas elements. SOLO taksonomija atspoguḷo virzišanos/secību no virspusējas mācīšanās uz mācǐšanos iedzị̣inoties (Biggs, \& Collis, 1982). Tomēr jāṇem vērā: jo kompleksāks mācǐšanās mērḳis, jo sarežgitīāk to nomērìt. Izpratne par kompetencēm kā prasmi tikt galā ar ikdienas dzìves kompleksajiem izaicinājumiem nozīmē, ka vērtēšanas metodēm jābūt attiecīgi uzlabotām, elastīgām un orientētām 
uz procesu (Hughes, Green, \& Greene, 2014, p. 27). Skolēnu iesaistīšana sevis un citu skolēnu vērtēšanā un atgriezeniskās saites sniegšanā un saņemšanā var veicināt mācǐšanos iedzil̦inoties (Boud, \& Feletti, 1998; Falchikov, \& Goldfinch, 2000).

Stundā, kurā notiek mācīšanās iedziḷinoties, atslēga ir uzdevums, kuru skolotājs izvēlas dot skolēnam, kā arī tas, kā tiek veidots mācību process, strādājot ar šo uzdevumu. Vai uzdevums dos iespēju skolēnam iedziḷināties (darboties produktīvi) vai paliks reproduktīvā līmenī (reproduktīvi - atkārtot definīcijas, vienkāršus skaidrojumus, veikt tipveida darbības pēc iepriekš zināma parauga un tml.)? (Petty, 2014). Vairāk par uzdevumu izvēles kritērijiem - 3. nodaḷā.

Salīdzinājumam aplūkosim divas pieejas (skat. 3. tabulu), kā veidot mācīšanos, veicot 2. attēlā redzamo uzdevumu.

3. tabula. Viena uzdevuma divas pieejas tā risināšanā

\begin{tabular}{|c|c|}
\hline Variants A & Variants B \\
\hline $\begin{array}{l}\text { Skolēniem nepieciešams zināt, ka } \\
\text { fosfātus izmanto kā ūdens mīkstinātāju, } \\
\text { jāzina fosfātjona kīmiskā formula, jāzina, } \\
\text { kuri joni nosaka ūdens cietību, un jāprot } \\
\text { uzrakstīt saīsināto jonu vienādojumu. Ja } \\
\text { skolēnam trūkst zināšanu par kādu no } \\
\text { nosauktajiem elementiem, tad viṇš nevar } \\
\text { atrisināt uzdevumu. }\end{array}$ & $\begin{array}{l}\text { Skolēni uzdevuma tekstā atrod, ka ūdens cietību } \\
\text { veido kalcija un magnija joni; attēlā dotajā etiketē ir } \\
\text { atpazīstami fosfātjoni, tekstā ir rakstīts, ka ūdens } \\
\text { cietību samazina, jonus izgulsnējot nešḳistošu } \\
\text { savienojumu veidā. Skolēnam ir pieejama šk̦īības } \\
\text { tabula, kurā ir atrodamas atbilstošo jonu formulas. } \\
\text { Atliek sastādīt prasīto saīsināto jonu vienādojumu. Ja } \\
\text { skolēnam ir izpratne, kā vispār veidojas vienādojums, } \\
\text { tad vin̄š spēj ar šo uzdevumu tikt galā bez specifisku } \\
\text { zināšanu atcerēšanās. }\end{array}$ \\
\hline
\end{tabular}

Variantā A mācīšanās tiek veidota, iegaumējot konkrētus faktus un formulas, variantā B jāiegaumē minimāls nepieciešamās informācijas daudzums (ḳ̂̄misko elementu simboli). Process tiek veidots, attīstot prasmes domāt, izmantot informāciju, kas atrodama uzdevuma tekstā, un lietot specifisku informācijas avotu (šḳīības tabulu). Abos gadījumos iespējams nonākt līdz risinājumam, bet mērķi, izvēloties vienu vai otru pieeju, ir principiāli atšķirīgi: vienā gadījumā process balstās uz iegaumēšanu, otrā - uz informācijas apstrādes prasmju attīstīšanu, spriestspēju u. c. kognitīvajām prasmēm. Salīdzinot mērḳi ìstermiṇā (dažas stundas, temata apguve u. c.) vai ilgtermiṇā (pabeigta skola, sāktas darba gaitas) - kas skolēnam ir noderīgāk, īpaši, ja karjera netiek saistīta ar ķīmiju? Šis piemērs parāda, ka l̦oti bieži noteicošais ir nevis tas, ko mēs mācāmies, bet gan tas, kādu mērḳi gribam sasniegt un kādā veidā ir uzbūvēts mācīšanās process, t. i., kādu pieeju ir izvēlējies skolotājs. 
5. uzdevums (9 punkti)

Katra mājā atrodas desmit dažādu sadzīves k̦īmijas produktu. Viens no tiem ir trauku mazgājamā mašīnā izmantojamās tabletes.

Sastāvs: 30\% - fosfāti, 5-15\% - skābekḷa bāzes balinātājs, < $5 \%$ - polikarboksilāti, nejonu virsmaktīvās vielas, fosfāti, enzīmi (proteāzes), amilāzes.

Ūdens satur dažādus izškīdušos sālus, tostarp kalcija un magnija sāḷs, kas veido ūdens cietību. Trauku mazgājamā mašīnā izmantojamo tablešu sastāvā ir viela, ar kurām novērš vai samazina ūdens cietību. To panāk, kalcija un magnija jonus izgusnējot neškīstošu savienojumu veidā.

5.1. Aplūko attēlu ar tabletes sastāvu un uzraksti kīimisko formulu vielai, kuru var izmantot kā ūdens mīkstinātāju šajās tabletēs!

5.2. Starp ūdenī esošajiem joniem un ūdens mīkstinātāju norisinās ḳīmiskā reakcija. Uzraksti jonu vienādojumu šai daḷai.

2. attēls. Uzdevums kịimijā 12. klasei (VISC, 2016)

Iepriekš aplūkotajā piemērā (skat. 2. attēlu), darot zināmu šo mērḳi skolēniem, tas ietvertu ne tikai konkrēto mācību saturu par cietu ūdeni. Vienā gadījumā skolēniem būtu jāzina, ka vini mācās iegaumēt šo saturu, otrā - ka viṇi mācās domāt, lietojot tekstā doto informāciju.

Kā pieeju atšķirīiba izpaužas, veidojot mācību aktivitātes stundā? Piemēram, dabaszinībās mācoties par putnu uzbūvi un funkcijām, skolotājam ir izvēle izmantot modeli ilustrācijai vai dot iespēju skolēniem vingrināties apgūt modelēšanas prasmi (skat. 4. tabulu).

\section{4. tabula Atškirīgas mācīšanas pieeju izvēles}

\begin{tabular}{lr}
\hline Modelis kā ilustrācija & Modelēšana kā skolēna prasme \\
\hline $\begin{array}{l}\text { Skolotājs demonstrē putna } \\
\text { modeli un parāda, kā uzbūve ir } \\
\text { saistīta ar funkcijām. }\end{array}$ & $\begin{array}{r}\text { 1. Skolēni modelē putnu, izmantojot dažādus materiālus } \\
\text { un darba lapu. }\end{array}$ \\
& $\begin{array}{l}\text { 2. Skolēni nosaka, kādas funkcijas veiks un kādā vidē } \\
\text { dzīvos citas grupas izveidots putns. }\end{array}$ \\
\hline Skolēni klausās, pieraksta. & $\begin{array}{l}\text { Skolēni apgūst uzbūvi un funkcijas, radoši modelējot, } \\
\text { izvērtējot, t. i., veicot dzillas domāšanas darbības. }\end{array}$ \\
\hline
\end{tabular}

Otrajā gadījumā (skat. 4. tabulu) skolēni ne tikai iepazīstas ar putnu uzbūvi un funkcijām, bet paši vingrinās modelēt. Iedziḷinās, kā uzbūve ir saistīta ar funkcijām un vidi. Modelēšanas prasmes attīstǐšana pamatojas Gilberta teorētiskajā 
modelī (skat. 3. attēlu), kas liecina, ka atbilstoši izvēlētajam mērḳim vispirms norisinās modelēšana kā prāta darbība, tad kā praktiska darbība, tad radītais modelis tiek izvērtēts un uzlabots, veicot šo ciklu vairākkārt. Alternatīvajā gadījumāa skolēns ir pasīvs skolotāja demonstrētā modeḷa vērotājs (Gilbert, 2004).

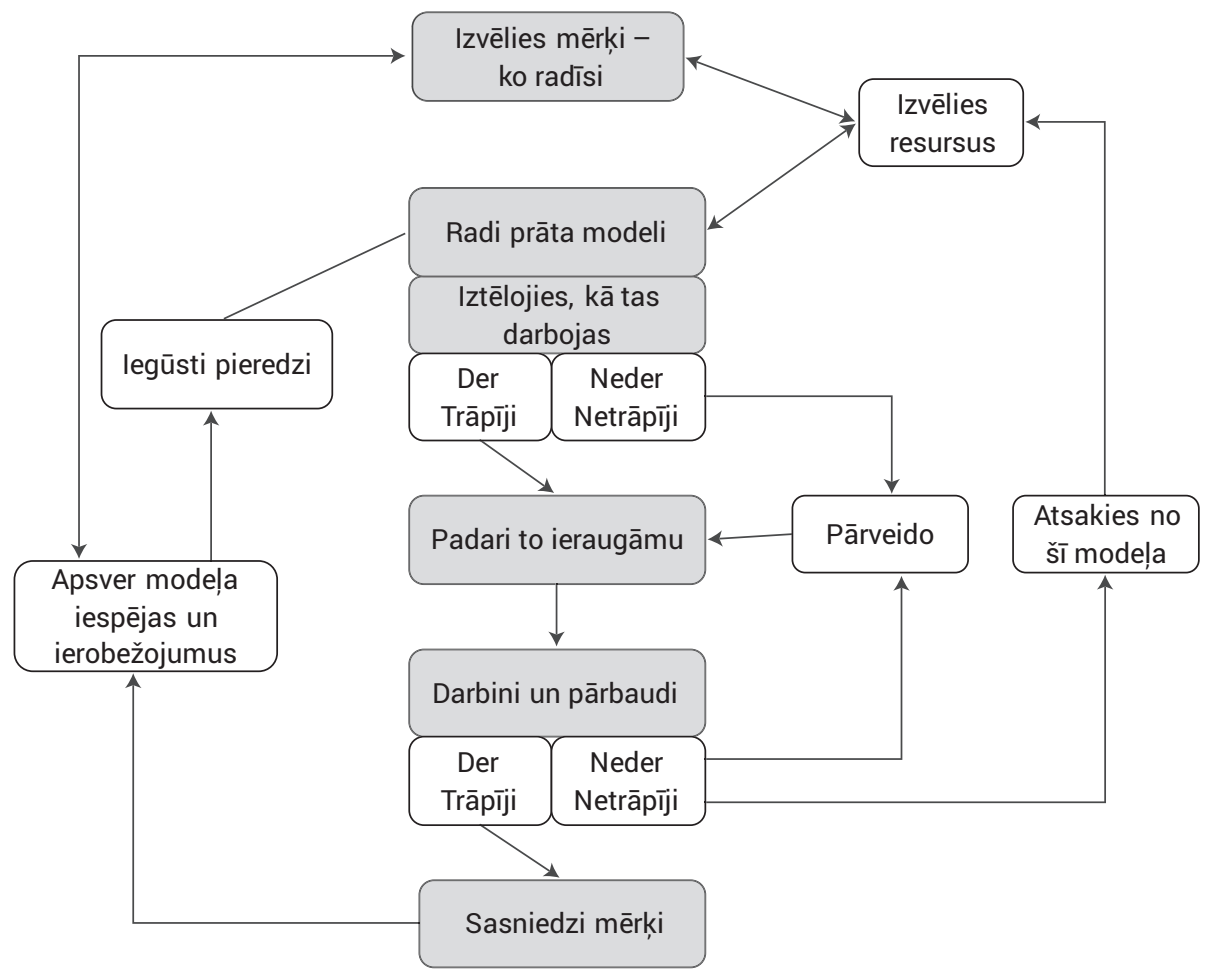

3. attēls. Modelēšana kā skolēna mācīšanās darbība (adaptēts pēc Gilbert, 2004)

Līdzīgas izvēles ir saistītas ar skolēnu pētnieciskās darbïbas (scientific inquiry) organizēšanu klasē u. c. Tikai no skolotāja ir atkarīgs, vai skolēnam ir iespēja apjēgt, kā strādā pētnieks, un gūt šādas mācīšanās pieredzi.

Piemērā aplūkosim skolēna mācīšanos iedziḷinoties fizikas stundā 8. klasē, kur skolotāja V. māca skolēniem eksperimentāli noteikt ķermeņa blīvumu. praktiskajam darbam (vārglāzes, svari, diegi utt.). Skolēni saṇem darba lapas, kurās ir uzdevumi. Skolotāja saka, ka stundas mērkis būs, strādājot pāros, pašiem noteikt doto kermeṇu (arī škidrumu) blīvumu un ka uzmanība tiks pievērsta arī sadarbībai. 
Uzdevumu varianti ir:

1. Noteikt blīvumu:

a) koka klucītim un pienam;

b) koka klucītim un dotajam škidrumam (nezināmam);

c) metāla armatūras stienim un kartupelim;

d) metāla armatūras stienim un ābolam.

2. Secīgi aprakstīt uzdevuma izpildes gaitu, iegūtos mērījumus un parādīt aprēkinu. Skolēni sāk darīt, sarunāties. Daži pāri uzreiz sāk darboties ar piederumiem. Viens n̦em armatūras gabalu, ṇem diegu un sien; cits lej vārglāzēēdeni utt.; citi sarunājas; kāds pāris pieraksta plānu, ko darīs utt. Skolotāja staigā un vēro skolēnus, iesaistās sarunās. Ir redzams, ka ar blīvuma noteikšanu metālam skolēni tiek galā, to ievietojot mērglāzē ar ūdeni. Skolēni dara, tad pieraksta, aprēkina. Atškiras, cik ātri katra grupa tiek uz priekšu. Veicot otro uzdevumu, ir grupa, kas lielu ābolu mēǵina ievietot mazā vārglāzē. Pie cita galda no ābola ir izgriezts ǵeometrisks gabaliṇš (gandrīz kubs). Viens pāris spriež, kā noteiks piena blīvumu. Skolēni ir ielējuši pienu divos traukos; un skolotāja jautā: "Vai tu domā, ka, ielejot divos traukos, piena blīvums atškirsies? Kāpēc tu tā domā?" Skolotāja uzdod jautājumus, cenšas neteikt priekšā. Pēc laika redzams, ka arī tie skolēni, kuri visu ābolu gribēja iedabūt vārglāzē, izgriež gabaliṇu.

Skolotāja dod uzdevumu telpas stūros kopā par darbu secību apspriesties tām grupām, kurām bija līdzīgi uzdevumi. Grupas aktīvi sarunājas; kāds jautā, kā vajadzēja darīt; cits stāsta; skolēni salīdzina rezultātus. Kāds pāris konstatē: "Sapratām, kā jādara", atstāj lielo grupu un dodas pabeigt savu darbu; skolotāja ieklausās sarunā; dod nākamo uzdevumu, lai katrs pāris komentē savu vērtējumu par iegūtajiem rezultātiem un apraksta izmantoto metožu plusus un minnusus.

Kāpēc šì ir mācǐšanās iedziḷinoties? Ir problēma. Otrajā piemērā skolēniem ir radīta jauna situācija (ābols, šķidrums), kad iepriekš redzētais nav pietiekams risinājumam. Nepieciešams salikt kopā visu vinuu rīcībā esošo informāciju, lai izvēlētos paņēmienu, kā darīt. Skolēni sarunājoties, sadarbojoties tiek paši galā plāno, izdomā, kā rīkoties; ja nepieciešams, mēǵina vairākas reizes. Ja iepriekšējais informācijas apjoms ir pietiekams, tad ir risinājums. Ja ir tāda vajadzība, skolēni saṇem atbalstu no klasesbiedriem vai skolotāja. Izpratne par to, kā darìt, veidojas pētnieciskā procesā. Vienlaikus šādas mācību pieejas izvēle dod iespēju skolotājam gūt labāku priekšstatu par skolēnu mācǐšanos. Pāri ir izvēelēti nejauši. Tikai ieklausoties sarunā, kas parāda, kā skolēni konkrētajā grupā domā, skolotājs ierauga, ko īsti skolēni saprot par to, kas ir blīvums un kā to ir iespējams noteikt; skolotājs uzzina radušos maldīgos priekšstatus un var plānot, kā ar tiem strādāt turpmāk. 
Skolotājs U. māca noteikt blīvumu atšķirīgi:

Skolēniem izdalîti dažādu materiālu, bet vienāda (zināma) tilpuma klucīši. Skolotājs aicina tos nosvērt un kopīgā sarunā secina, ka dažādām vielām vienāda tilpuma objektiem ir dažādas masas, tātad kaut kas atškiras pašā vielā. Skolotājs stāsta, ka šis lielums ir blīvums. Skolotājs izstāsta blīvuma definīciju, aicina to pierakstīt kladē, parāda skolēniem blīvuma aprēkināšanas formulu uz tāfeles, aicina to pierakstīt kladē, izskaidro visus lielumus un mērvienības, izrēkina kopīgi vienu piemēru. Izrunā, ka labi cilvēki jau sarēkinājuši vielu blīvumus un apkopojuši tos tabulās. Parāda, kā atrast blīvumu tabulā. ledod katram pārim trīs koka klucīšus vai metāla cilindrus un, mērot un aprēkinot pēc dotās formulas, liek noteikt, no kādas koksnes vai metāla tie izgatavoti. Skolēnam pieejams lineāls un atsperes svari. Skolēni rēkinina, tabulās atrod vistuvāko materiālu.

Kāpēc šì nav mācǐšanās iedziļinoties? Skolēni rīkojas tipveida situācijā - klausās skolotāja teikto, pieraksta definīciju, no tāfeles noraksta paraugu, kā aprēķina blīvumu; vēro paraugu, kā skolotājs atrod blīvumu tabulā; tad ilustrē apgūto praktiski nosaka ķermen̦a blīvumu, mērot masu un tilpumu un aprēķinot to pēc dotas formulas.

5. tabulā apkopotas pazìmes, kas raksturo mācīšanās iedziḷinoties pieejas īstenošanu mācību stundā no skolotāja darbību viedokḷa. Tabula veidota kā praktisks rīks skolotāja darba pašnovērtējumam un refleksijai, vienaudžu savstarpējam vērtējumam, lai attīstītu un nostiprinātu mācī̌sanās iedziḷinoties praksi skolotāju ikdienas darbā. Pazīmes atvasinātas no teorētiskās literatūras apskata un skolotāju stundu vērojumiem periodā no 2011. līdz 2017. gadam un tālāk pilnveidotas LU SIIC darbā, īstenojot pedagogu profesionālo pilnveidi.

Lai notiktu mācǐšanās iedziḷinoties, tiek veikta iepriekšèjā satura aktualizācija. Jaunā satura apjēgšana tiek veidota, paplašinot esošo, iepriekš apgūto pieredzi un dodot iespēju jaunapgūto lietot, darbināt un par to reflektēt. Papildus tiek vingrinātas prasmes, lai panāktu, ka skolēns apzināti var izteikties par to, ko nozīmē novērot, secināt, strukturēt informāciju, izvērtēt savu darbu pret plānoto, un kā to dara. 
5. tabula. Mācību stundu analīzes lapa "Skolotājs stundā vada mācīšanos iedzilinoties" (LU SIIC arhīvs)

\begin{tabular}{lcc}
\hline Skolotājs stundā & Ir/nav & $\begin{array}{c}\text { Pierādījumi mācību } \\
\text { stundā vērotajam }\end{array}$ \\
\hline
\end{tabular}

\section{Sagatavo, lai notiek mācīšanās:}

- komunicē skolēniem sasniedzamo rezultātu

- aktualizē skolēnu pieredzi

- rosina skolēnu interesi

\section{Vada mācišanos}

Izvēlas mācību uzdevumus:

- tie virza uz sasniedzamo rezultātu

- tie ir produktīvi - dod iespēju skolēnam pašam konstruēt zināšanas

- uzdevumu un mācību aktivitāšu secība skaidra, pamatota, savstarpēji saistīta

Komunicē uzdevumus:

- dod skaidrus, saprotamus norādijjumus

- uzdevumam ir atbalsta struktūra, kas palīdz darīt

Veicina, atbalsta mācīšanos:

- iesaista skolēnus

- skolēniem ir pietiekami daudz laika, lai domātu

- diferencē uzdevumus un aktivitātes atbilstoši skolēnu spējām, vajadzībām

Metakognitīvais līmenis:

- māca metakognitīvās stratēǵijas, rosina skolēnus domāt par to, ko un kā dara

\section{Sadarbības organizēšana un mācīšana}

Izmanto un māca skolēnus izmantot dažādus mācību rīkus, līdzeklus:

- IT

- piederumus, ierīces

- dažādus informācijas avotus

Dod atgriezenisko saiti skolēniem

- konstatē rezultātu - iegūst informāciju par sasniegto

- dod skolēniem izmantojamu atgriezenisko saiti, lai uzlabotu mācīšanos

- māca skolēnus dot un saṇemt atgriezenisko saiti 


\section{Secinājumi}

Lai skolēna mācīšanās rezultāts būtu kompetence, kas pēc savas būtības ir kompleksa un ietver gan zināšanas, gan prasmes un attieksmes, kā arī spēju šos atsevišķos elementus integrēt saskan,otā, mērḳtiecīgā un atbildīgā rīcībā, skolotājiem svarīgi īstenot mācī̌sanās iedzilinoties pieeju - plānot un veidot procesu, kura laikā skolēns attīsta spēju vispārināt, pārnest jaunās zināšanas un prasmes uz nezināmām situācijām (tostarp reālās dzīves situācijām), mācǐšanas priekšplānā izvirzot procesus, ar kuru palīdzību mēs iegūstam zināšanas (kā mēs zinām?), ne tikai uzkrātu noteiktu satura apjomu (ko mēs zinām?). Īstenojot metodisko pieeju, kas virza mācīšanos iedzị̣inoties, skolotājs dod iespēju skolēnam attīstīt augsta līmeņa kognitīiās prasmes - analizēt, sintezēt, izvērtēt, risināt problēmas, attīstīt metakognitīvās prasmes, lai skolēns spētu konstruēt apgūtā jēgu un izmantot pieredzi, risinot kompleksus uzdevumus jaunās situācijās un kontekstā.

Novērojumi stundās liecina, ka šie mācī̌sanās iedzilịnoties elementi sastopami atsevišķu skolotāju praksē, taču tie nav pietiekami bieži novērojami sistēmas līmenī. Nepieciešama akcentu maiņa mācī̌anas pieejā:

- no gatavu zināšanu nodošanas un atprasišsanas uz jautāšanu, sarunu, situāciju analīzi, produktīviem uzdevumiem, radot jaunas zināšanas;

- no frontāla procesa uz iesaistišanos un sadarbību;

- no faktologisku zināšanu iegaumēšanas uz zināšanu lietošanu daudzveidīgās situācijās un kontekstā, lai skolēni iegūtu šādas vingrināšanās un pārnesuma veidošanas pieredzi;

- no tikai summatīvās vērtēšanas uz jēgpilnu atgriezenisko saiti par mācīšanās procesu, refleksiju, mācīšanās apzināšanos.

Lai skolēnu mācišanās rezultāts būtu kompetence, skolu praksē nepieciešams:

- katram skolotājam darbu klasē virzìt uz iedziḷināšanos; mainìt veidu, kā skolas līmenī tiek plānots un organizēts mācību saturs un vērtēšana.

\section{IZMANTOTĀ LITERATŪRA}

Andrade, H. L., \& Heritage, M. (2017). Using Formative Assessment to Enhance Learning, Achievement, and Academic Self-Regulation. Routledge.

Biggs, J. (1987). Student approaches to learning and studying. Melbourne: Australian Council for Educational Research.

Biggs, J., Kember, D., \& Leung, Y. (2001). The revised two-factor study process questionnaire: R-SPQ-2F. British Journal of Educational Psychology, 71, pp. 133-149.

Biggs, J. B., \& K. F. Collis. (1982). Evaluating the quality of learning: The SOLO taxonomy. New York: Academic. 
Bloom, B. S. (ed.). (1956). Taxonomy of educational objectives: the classification of educational goal. New York: Longmans Green.

Boud, D., \& Feletti, G. (1998). The challenge of problem-based learning. London: Routledge.

Boulton-Lewis, G. M., Smith, D. J. H., McCrindle, A. R., Burnett, P. C., \& Campbell, K. J. (2001). Secondary teachers' conceptions of teaching and learning. Learning and instruction, 11(1), pp. 35-51.

Chin, C., \& Brown, D. E. (2000). Learning in science: A comparison of deep and surface approaches. Journal of research in science teaching, 37(2), pp. 109-138.

Entwistle, N. (2001). Conceptions, styles and approaches within higher education: Analytic abstractions and everyday experience. In Perspectives on cognitive, learning, and thinking styles, Sternberg, R. \& Zhang, L. F. (eds.). pp. 103-36. Mahwah, NJ: Erlbaum.

Falchikov, N., \& Goldfinch, J. (2000). Student peer assessment in higher education: A meta analysis comparing peer and teacher marks. Review of Educational Research, 70(3), pp. 287-322.

Fullan, M., \& Langworthy, M. (2013). Towards a new end: New pedagogies for deep learning. Seattle, Washington: Collaborative Impact.

Fullan, M., \& Langworthy, M. (2014). A rich seam: How new pedagogies find deep learning. MaRS Discovery District.

Fullan, M., \& Scott, G. (2014). New pedagogies for deep learning. Whitepaper: Education PLUS.

Gardner, H., \& Perkins, D. N. (1988). Art, mind, and education: Reasons from project Zero. Champaign: University of Illinois Press.

Gilbert, J. K. (2004). Models and modelling: Routes to more authentic science education. International Journal of Science and Mathematics Education, 2(2), pp. 115-130.

Greene, J. A., \& Azevedo, R. (2009). A macro-level analysis of SRL processes and their relations to the acquisition of a sophisticated mental model of a complex system. Contemporary Educational Psychology, 34(1), pp. 18-29.

Hattie, J. (2009). Visible Learning. A synthesis of over 800 meta-analysis relating to achievement. Routledge, London and New York (Appendix A).

Hattie, J. (2012). Visible learning for teachers: Maximizing impact on learning. Routledge. Hattie, J., \& Yates, G. C. (2013). Visible learning and the science of how we learn. Routledge. Hughes, S., Green, C., \& Greene, V. (2014). Report on current state of the art in formative and summative assessment in IBE in STM-Part 2. Pieejams: http://assistme.ku.dk/resources/ report_series/ (aplūkots 7.11.2017.).

Lampert, M. (2015). Deeper teaching. Boston, MA: Jobs for the Future. Pieejams: https:// jfforg-prod-prime.s3.amazonaws.com/media/documents/Deeper-Teaching-120315.pdf (aplūkots 07.11.2017.).

Marton, F. (1983). Beyond individual differences. Educational Psychology, 3, pp. 289-303.

Marton, F., \& Säljö, R. (1984). Approaches to learning. In Marton, F., Hounsell, D., \& Entwistle, N. (eds.). The experience of learning. Edinburgh: Scottish Academic Press.

Niaz, M. (2008). Whither constructivism? - A chemistry teachers' perspective. Teaching and Teacher Education, 24(2), pp. 400-416.

O’Toole, M. T. (2005). Miller-Keane Encyclopedia \& Dictionary of Medicine, Nursing \& Allied Health ( $7^{\text {th }}$ Ed.). Philadelphia: WB Saunders.

Petty, G. (2014). Evidence-based teaching. Oxford University Press. 
Ramsden, P. (1988). Context and strategy: Situational influences on learning. In Schmeck, R. R. (ed.). Learning strategies and learning styles, pp. 159-184. New York: Plenum.

Reece, I., \& Walker, S. (2016). Teaching, training and learning: A practical guide $\left(6^{\text {th }}\right.$ ed.). Business Education Publishers Ltd.

Schunk, D. H., \& Zimmerman, B. (eds.). (2011). Handbook of self-regulation of learning and performance. Taylor \& Francis.

Smith, T. W., \& Colby, S. A. (2007). Teaching for deep learning. The Clearing House: A Journal of Educational Strategies, Issues and Ideas, 80(5), pp. 205-210.

Smith, T. W., Gordon, B., Colby, S. A., \& Wang, J. (2005). An examination of the relationship between depth of student learning and National Board Certification status. Office for Research on Teaching, Appalachian State University. Pieejams: http://images3.cersp.com/ blog2/uploadfiles/2006-12/1210107137.pdf (aplūkots 01.11.2017.).

Trigwell, K., Prosser, M., \& Waterhouse, F. (1999). Relations between teachers' approaches to teaching and students' approaches to learning. Higher education, 37(1), pp. 57-70.

Vos, N., van der Meijden, H., \& Denessen, E. (2011). Effects of constructing versus playing an educational game on student motivation and deep learning strategy use. Computers \& Education, 56(1), pp. 127-137. 